\author{
REVIEW OF EUROPEAN AND COMPARATIVE LAW \\ VOLUME XLVII \\ YEAR 2021, ISSUE 4 pp. 157-187 \\ DOI: https://doi.org/10.31743/recl.12727
}

\title{
MEDIEVAL CANON LAWYERS AND EUROPEAN LEGAL TRADITION. A BRIEF OVERVIEW
}

\author{
Tomasz Giaro*
}

\begin{abstract}
The Roman Church was a leading public institution of the Middle Ages and its law, canon law, belonged to most powerful factors of European legal history. Today's lawyers have hardly any awareness of the canonist origins of several current legal institutions. Together with Roman law, canon law constituted the system of "both laws" (utrumque ius) which were the only laws acknowledged as "learned" and, consequently, taught at medieval universities. The dualism of secular (imperium) and spiritual power (sacerdotium), symbolized by so-called two swords doctrine, conferred to the Western legal tradition its balance and stability. We analyze the most important institutional achievements of the medieval canon lawyers: acquisitive prescription, the Roman-canonical procedure, the theory of just war, marriage and family law, freedom of contract, the inheritance under will, juristic personality, some institutions of constitutional law, in particular those based on the concept of representation, and finally commercial law. Last not least, the applicability of canon law defined the territorial extension of medieval and early modern Christian civilization which exceeded by far the borders of the Holy Roman Empire, where Roman law was effective as the law of the ruler. Hence, the first scholar to associate Roman law with (continental) Europe as a relatively homogeneous legal area, Paul Koschaker, committed in his monograph Europa und das römische Recht, published in 1947, the error of taking a part for the whole. In fact, Western legal tradition was based, in its entirety, not on Roman, but rather
\end{abstract}

Prof. Dr. habil. Tomasz Giaro, Professor, Faculty of Law and Administration, University of Warsaw; correspondence address: Krakowskie Przedmiescie 26-28, 00-927 Warsaw, Poland; e-mail: giaro@uw.edu.pl; https://orcid.org/0000-0002-5702-6135. 
on canon law; embracing the common law of England, it represented - to cite Harold Joseph Berman - the first great "transnational legal culture". At the end, some structural features of canon law are discussed, such as the frequent use of soft-law instruments and the respect for tradition, clearly visible in the approach to the problem of codification.

Keywords: canon law sources, two swords doctrine, utrumque ius, transnational law, soft law, codifications

\section{SOME GENERAL REMARKS}

East and West. The border between East and West in the framework of European legal culture or, maybe somewhat more exactly, European legal tradition, is in reality the border between Eastern and Western Christendom. Whereas the political systems of the East, based on the legacy of the Byzantine Empire, relied on a power structure that, even if not entirely monolithic, was at least characterized by the clear supremacy of secular over spiritual power, the political culture of Western Christianity consisted in an equitable dualism of regnum (imperium) and sacerdotium ${ }^{1}$. At the legal level, this dualism found expression, notably, in a twofold system of "both laws" (utrumque ius) - Roman and canon².

The sharp distinction between religious and political power is a direct consequence of the universalism of Christianity which, like many contemporary religions, transcends the borders of nations and countries ${ }^{3}$. In fact, within the framework of Western civilization, Christianity was the first religion to emancipate itself from the state. Moreover, as already mentioned, this new religion produced its own legal system, which was characterized in the later Roman legislation as lex christiana (CTh. 1.27.1) or

1 Brian Tierney, Church Law and Constitutional Thought in the Middle Ages (London: Variorum Reprints, 1979); Marie Theres Fögen, "Das Politische Denken der Byzantiner," in Pipers Handbuch der politischen Ideen, vol. II, ed. Iring Fetscher and Herfried Münkler (München, Zürich: Piper Verlag, 1993), 41-85.

2 Tomasz Giaro, "Europejska geneza polskich zasad i wartości konstytucyjnych," Państwo Prawne 3 (2013): 9.

3 Remigiusz Sobański, Europa obojga praw (Katowice: Księgarnia Św. Jacka 2006), $35-38$ 
lex catholica (CTh. 16.2.11) $)^{4}$. During the High Middle Ages, the dualism of imperium and sacerdotium, separating secular from religious authority, took the personalized form of the contest between Emperor and Pope.

Spiritual and secular matters. In the venerable city of Rome on Christmas Day of the year 800, Pope Leo III crowned as Emperor the King of the Franks and Longobards, Charlemagne, who exercised authority in that capacity as the "administrator of the Roman Empire" (Romanum gubernans imperium). The crowning ritual was accomplished on grounds of the so-called transfer of power (translatio imperii) - essentially a pure legal fiction which implied the historical continuity of the Empire from antiquity to the Middle Ages. Yet already in Charlemagne's Empire, symbolically "transferred" from the ancient Western Empire of Rome (Imperium Occidentis), spiritual matters were precisely delimited from secular ones 5 .

In high medieval Poland, this dualism of spiritual and secular jurisdiction is best illustrated by the conflict between King Boleslaw II the Generous (or the Bold), crowned in 1076, and Cracow's Bishop Stanislas of Szczepanów. Their dispute over sexual morality ended with the excommunication of the King by the Bishop who forbade the canons of Cracow Cathedral from praying the Office in case Boleslaw might be in attendance. However, the King's subsequent denunciation of Bishop Stanislas for treason revealed that their conflict, terminated in 1079 with the bishop's murder, exemplified only - as a similar later case of Archbishop Thomas Becket and King Henry II of England - the conflict between secular and canon law ${ }^{6}$.

The Church as a leading institution. The current image of canon law corresponds to its reduced condition of a poor remnant from the glorious past. But during late antiquity and Early Middle Ages, the Church of

4 Wolfgang Kaiser, Authentizität und Geltung spätantiker Kaisergesetze (München: C.H. Beck 2007), 321.

5 Peter Brown, The Rise of Western Christendom. Triumph and Diversity (Malden MA, Oxford: Blackwell 1998), 297-298.

6 Roman Grodecki, Sprawa św. Stanistawa (Kraków: Wydawnictwo Literackie, 1979); Wacław Uruszczak, "Les répercussions de la mort de Thomas Becket en Pologne," in Opera Historico-Iuridica Selecta (Kraków: Jagiellonian University Press, 2017), 53-61. 
Rome was an important social institution which preserved ancient heritage, thereby literally saving it from destruction. Furthermore, the medieval Church stood as the leading public institution in Western Europe ${ }^{7}$. Where state courts failed, there was bishop's jurisdiction (episcopalis audientia) ${ }^{8}$. However, despite this historic centrality, the achievements of canon law are nowadays so miserably faded that it would be rare for a modern lawyer to have any awareness of the canonist origins of several present-day legal institutions.

According to a renown saying ecclesia vivit lege Romana, the universal Roman Church lived during the Middle Ages by Roman law ${ }^{9}$. From this point of view, it seems legitimate to consider canon law as a more or less extensive modification to the ancient Roman law as transmitted to posterity in the $6^{\text {th }}$ century Byzantium by Justinian's compilation. Nevertheless, the social and legal importance of these modifications impels us to view the achievements of medieval canon lawyers in another light, namely as historical foundations of modern law. It was exactly canon law which essentially influenced European legal tradition and, moreover, delimited the borders of the international community of that time ${ }^{10}$.

\section{SOURCES OF CANON LAW}

Decretum Gratiani. Canon law was, however, traditionally considered as somehow inferior to Justinian's compilation which was older and employed numerous intellectually advanced methods of juristic

7 Brown, The Rise, 319-320.

8 Brown, The Rise, 103-104; A.J. Boudewijn Sirks, "The episcopalis audientia in Late Antiquity," Droit et Cultures 65 (2013): 79-88; Marzena Wojtczak, "Audientia sacerdotalis? Remarks on the Legal Nature of Dispute Resolution by Ecclesiastics in Late Antiquity," Zeitschrift für Antikes Christentum 25.1 (2021): 108-149.

9 Richard Henry Helmholz, The Spirit of Classical Canon Law (Athens GA: The University of Georgia Press, 1996), 17-20; Antoni Dębiński, Church and Roman Law (Lublin: Wydawnictwo KUL, 2010), 44-61.

10 Tomasz Giaro, "Legal Historians and the Eastern Border of Europe," in Methodenfragen der Romanistik im Wandel, ed. Tommaso Beggio and Aleksander Grebieniow (Tübingen: Mohr Siebeck, 2019), 147-164. 
interpretation, as well as legal arguments and techniques. On the other hand, about 1140 , a collection of the rules of Church law appeared ${ }^{11}$. Its author was Gratian, a canon lawyer from Bologna, who was possibly also a Camaldolese monk. The name under which this authoritative collection of canon law material was issued, read Concordia (or Concordantia) Discordantium Canonum which meant "Harmony - or Concordance of Divergent Norms", but it was better known simply as the Decretum Gratiani or the Decretum ${ }^{12}$.

The sources of the Decretum were the Bible, Justinian's compilation, the Church Fathers, papal decretals (litterae decretales), as well as the acts and decrees of synods and councils of the Christian Church. The Decretum marked the starting point of the development of canon law into a kind of system, even if a very loose one. Its body of doctrine, contained in the first part and divided in 101 distinctiones, was similar to Justinian's compilation of Roman law, first of all in view of uncritical and unsystematic arrangement. The second part of the Decretum included brief annotations, called dicta Gratiani, which resolved 36 fictitious cases (causae). The third part, titled De consecratione, analyzed, within 5 distinctions, the sacraments ${ }^{13}$.

Later sources. After the publication of the Decretum Gratiani much papal legislation appeared. In 1230, the Decretum was united with the papal decretals which consisted of letters containing pope's decisions addressing particular questions and directed to individuals. In 1234, Pope Gregory IX promulgated a large collection of new papal decretals called - because of its location outside the Decretum - Liber Extra, edited by the Catalan Dominican friar Raymond of Peñyafort. In 1298, Pope Boniface VIII issued a further collection called, as a new book added to the five

11 Peter Stein, Roman Law in European History (Cambridge: Cambridge University Press, 1999), 49-51.

12 Peter Landau, "Gratian and the Decretum Gratiani," in The History of Medieval Canon Law in the Classical Period, ed. Wilfried Hartmann and Kenneth Pennington (Washington DC: The Catholic University of America Press, 2008), 22-54; Helmholz, The Spirit, 7-10, 178-185.

13 Eltjo J.H. Schrage, Utrumque Ius. Eine Einführung in das Studium der Quellen des mittelalterlichen gelehrten Rechts (Berlin: Duncker \& Humblot, 1992), 93-95. 
compiled by Raymond, Liber Sextus, and in 1314 Pope Clement V began the publication of the so-called (Decretales) Clementinae ${ }^{14}$.

In 1582, after the Council of Trent (1545-1563) which consolidated the Roman Catholic faith against the beliefs of the Protestant Reformation, Pope Gregory XIII disseminated an official critical compilation of all canon law materials ranging from the Decretum Gratiani to the later decretals, issued during the $14^{\text {th }}$ and $15^{\text {th }}$ centuries. Since the end of the $16^{\text {th }}$ century, the compilation was styled the Corpus Iuris Canonici, a designation mirroring the secular Corpus Iuris Civilis. As a matter of fact, the latter, from the time of its publication in 1583 by the French humanist jurist Denis Godefroy (Dionysius Gothofredus) in the first critical complete edition, printed at Geneva, signified for the era the whole body of Roman law ${ }^{15}$.

The influence of the Decretum. The Decretum Gratiani inspired the activity of recording secular local laws (iura propria) throughout Europe ${ }^{16}$. Indeed, the conviction that written legislation was possessed of higher dignity generated several collections of customary law in different territories during the $13^{\text {th }}$ century. The most influential in Central Europe was the Sachsenspiegel, or the "Mirror of the Saxons", published in 1220-35 by a free German noble Eike of Repgow in Magdeburg17. Like the Decretum, the Sachsenspiegel also ordered the customs observed in Saxony in a purely associative manner, merging norms and institutions of public and private law, criminal law, property and successions, jurisdiction and procedure.

The Sachsenspiegel enjoyed a vast influence. Its progeny were the Deutschenspiegel of 1274, Schwabenspiegel of 1275, and Frankenspiegel

14 Manlio Bellomo, The Common Legal Past of Europe 1000-1800 (Washington DC: The Catholic University of America Press, 1995), 73-74.

15 Raoul C. van Caenegem, An Historical Introduction to Private Law (Cambridge: Cambridge University Press, 1992), 64.

16 Kenneth Pennington, "Western Legal Collections in the Twelfth and Thirteenth Centuries," in Religious Minorities in Christian, Jewish and Muslim Law (5th-15th Centuries), ed. Nora Berend, Youna Hameau-Masset et al. (Tournhout: Brepols Publishers, 2017), 92-98.

17 Hans Hattenhauer, Europäische Rechtsgeschichte, $2^{\text {nd }}$ ed. (Heidelberg: C.F. Müller, 1994), 264-67; Friedrich Ebel and Georg Thielmann, Rechtsgeschichte. Ein Lehrbuch, vol. I (Heidelberg: C.F. Müller, 1989), 140-146. 
of 1328-38. Moreover, similar collections appeared in Western Europe slightly earlier or later: in England, before 1190 a practical account of the remedies of the King's courts, Tractatus de legibus et consuetudinibus Angliae attributed to Ranulf de Glanvill, and before 1268 the similarly titled work labeled Henry de Bracton; in Spain, the collections of local Germanic laws called Fueros; and in France, records of local customs, particularly the Coutumes de Beauvaisis, drafted by Philippe of Beaumanoir around 1280. The Sachsenspiegel influenced medieval Hungarian town law as well ${ }^{18}$.

\section{THE SYSTEM OF "BOTH LAWS"}

Utrumque ius. Canon law was the product of ecclesiastical sources and their interpretation. Gratian's followers, called decretists, started to produce new glosses and collect the existing ones in a way essentially similar to the glossators of Roman law. In the $13^{\text {th }}$ and $14^{\text {th }}$ centuries there emerged a strong competition between commentators on civil (i.e. Roman) and canon law. On the other hand, although the two bodies of law differed, and the work of jurists in each field remained distinct in content and application ${ }^{19}$, canon and civil law were so intertwined that neither could be understood without the other: civilista sine canonista parum valet, canonista sine civilista nihil. Hence, many lawyers were schooled in both civil and canon law ${ }^{20}$.

In principle, civil law was concerned with justice directed towards worldly happiness and prosperity, whereas the remit of canon law was the soul's salvation (salus animae). Canon law and civil law interacted

18 Nadja El Beheiri, "Der Einfluss des Sachsenspiegels auf die Entwicklung des ungarischen Rechts im Mittelalter," in Sachsen im Spiegel des Rechts. Ius Commune Propriumque, ed. Adrian Schmidt-Recla et al. (Köln, Weimar, Wien: Böhlau, 2001), 79-93.

19 James Gordley, The Jurists. A Critical History (Oxford: Oxford University Press, 2013), 51-81.

20 James A. Brundage, The Medieval Origins of the Legal Profession (Chicago, London: The University of Chicago Press, 2008), 123-125; Hermann Lange and Maximiliane Kriechbaum, Römisches Recht im Mittelalter, vol. II. Die Kommentatoren (München: C.H. Beck, 2007), 209-215. 
constantly following the principle of complementarity: on the one hand, in the absence of canon law norms, ecclesiastical courts were expected to apply civil law, and on the other, secular courts regularly took into consideration general principles of canon law. Moreover, against the protests of the legists (legistae), who specialized in the study of secular law, the Roman Church strove to expand the number of cases involving a spiritual element and, therefore, the scope of the ecclesiastical jurisdiction ${ }^{21}$.

In fact, several rules belonging to the ordinary private and criminal law were applied also within ecclesiastical jurisdiction. All in all, on subject-matter grounds (ratione materiae), canon law governed cases involving a spiritual element (matters spiritual, causae mere spirituales), such as marriage, as well as related cases (causae spiritualibus annexae), i.e. cases about ecclesiastical property, tithes, wills and contracts made under oath. Finally, the ecclesiastical jurisdiction also encompassed cases whose distinct feature was the personal status (ratione personae), in which either clerics were summoned, or disadvantaged persons, such as poor, widows and orphans (personae miserabiles), were involved ${ }^{22}$.

The two swords doctrine. The complicated relation between secular and spiritual law was frequently manifested in their concurrent applicability. The Sachsenspiegel begins with the so-called 'two swords' doctrine, connoting the equivalence of both spiritual and secular power. The doctrine was definitively formulated during the so-called Papal Revolution of the years 1050-1150 in connection with the investiture controversy of that time ${ }^{23}$. The authorship of the doctrine was ascribed to Pope Gelasius I (492-496) who, in a letter to the East Roman Emperor Anastasios I (491-518), was supposed to have invented the dual understanding of powers in the state, imperial and episcopal, without giving precedence to any of them.

During the Papal Revolution these supremacy claims were cleverly renewed by Pope Gregory VII (1073-1085), hearkening back to the biblical metaphor of two swords (Luke 22.38) delivered by God himself to

21 Bellomo, The Common Legal Past, 76-77.

22 Helmholz, The Spirit, 116-144; Maximiliane Kriechbaum, "Die Zuständigkeiten der kirchlichen Gerichte im Spiegel der Legistik,” Glossae 13 (2016): 361-370.

23 Helmholz, The Spirit, 338-365; Stein, Roman Law, 41-43. 
the emperor and the pope $\mathrm{e}^{24}$. The canonist interpretation, integrated into the Decretum Gratiani (D. 96, c. 10), dogmatized the natural superiority of the spiritual power, which was the sole universal power, over the temporal. The Decretum proceeded on the basis that God had originally delivered both swords to the pope who only subsequently ceded the secular one to the emperor. By contrast, the interpretation promoted by the legists or civilians asserted a relation of equality between the two powers ${ }^{25}$.

Acquisitive prescription. This legal institution became the subject of direct contestation since the 1215 constitution of Pope Innocent III introduced the requirement of continuous good faith. Hence, the canonists formulated the principle that "supervening bad faith undermines the prescription" (mala fides superveniens nocet), subsequently included in the "Decretals" (X. 2.26.20) ${ }^{26}$. Against the ancient Roman law (ius civile), which required good faith exclusively at the moment of the entry in possession and not later (mala fides superveniens non nocet), the canonists argued that attaining profit from bad faith is always immoral, since everything not descending from (good) faith is a sin (Romans 14.23 peccatum) ${ }^{27}$.

The canonists' restrictive reframing of the acquisitive prescription penetrated in due course into secular private law of main continental countries $^{28}$. Their civil codifications of the $19^{\text {th }}$ century are divided on the matter. The Roman rule was adopted by the French code civil (art. 2269), the Italian codice civile (art. 1161), the Greek astikos kodix (art. 1044),

24 Randal Lesaffer, European Legal History. A Cultural and Political Perspective (Cambridge, New York: Cambridge University Press, 2009), 214-216.

25 Bellomo, The Common Legal Past, 75-76.

26 Willem Jans Zwalve and Boudejiwin Sirks, Grundzüge der Europäischen Rechtsgeschichte. Einführung und Sachenrecht (Wien, Köln, Weimar: Böhlau, 2012), 292, 326.

27 Emilio Bussi, La formazione dei dogmi di diritto privato nel diritto comune. vol. I (Padova: Cedam, 1937), 66-72; Łukasz Korporowicz, "Roman Law Behind the Decrees 39-41 of the Fourth Lateran Council," in The Fourth Lateran Council and the Development of Canon Law and the ius commune, ed. Atria A. Larson et al. (Turnhout: Brepols, 2018), 235-250; Andrea Massironi, "Prescrizione e buona fede acquisitiva: la costituzione Quoniam omne (c.41) nell'interpretazione della canonistica medievale,” ibid., 251-279.

28 Olivia F. Robinson, T. David Fergus, and William M. Gordon, European Legal History. Sources and Institutions, $3^{\text {rd }}$ ed. (London, Edinburgh, Dublin: Butterworths, 2000), 88-89. 
and the Dutch burgerlijk wetboek (art. 3:118), whereas the canonist one found favour in the Austrian ABGB ( $\$ 1463)$, the German BGB $(\$ 937)$ and the Swiss ZGB (art. 728). Under the Polish civil code of 1964, supervening bad faith precludes the acquisition of movables (art. $174 \mathrm{KC}$ ), but in respect of immovables the more lenient Roman rule remains in force (art. $172 \mathrm{KC}$ ).

Roman-canonical procedure. The "mother of all procedures" on the continent is a supreme example of synthesis between the two laws ${ }^{29}$. As a result of the Papal Revolution, started in the $11^{\text {th }}$ century, the ecclesiastical jurisdiction expanded; specifically, breach of contract and tort also came to be considered sins and thus constituted effective foundations for actions launched before the ecclesiastical courts. During the $13^{\text {th }}$ century the "learned" Roman-canonical procedure spread in due course across Europe, from ecclesiastical to secular courts. It was first outlined in the work Speculum iudiciale ("Mirror of Justice"), penned by the French canonist, Bishop Guillaume Durand (or William Durantis) and published in 1271-76.

The Roman-canonical procedure was born in the Church courts and arbitrations led by ecclesiastical authorities. It was based upon the late Roman procedure called cognitio extra ordinem from which it borrowed several positive features. Following the Roman cognitio, it allowed appeal to a higher court, but on the other hand, the proceedings were private, less formal than the contemporary Germanic tribal procedure, written, and generally required the presence of witnesses and documents. The judge was not a commoner, but from the beginning a professional university-educated episcopal functionary. He both investigated the case and pronounced the sentence. The Roman-canonical procedure was documentary in character.

Accordingly, all procedural stages involving the statements of the parties, their advocates and the judge, complete with the testimony of witnesses, were set down in writing ${ }^{30}$, following the maxim "what is not re-

29 Cornelius H. van Rhee, "English and Continental Civil Procedure. Similarities Today and in the Past," in Studies in Honour of Wiestaw Litewski, ed. Janusz Sondel et al., vol. II (Kraków: Jagiellonian University Press, 2003), 201-216.

30 Wiesław Litewski, Der römisch-kanonische Zivilprozess nach den älteren ordines iudiciarii, vol. I (Kraków: Jagiellonian University Press, 1999), 66-67. 
corded in the acts, does not exist in the world" (quod non est in actis, non est in mundo $^{31}$. Furthermore, the Roman-canonical procedure was governed by two allied principles of party control: first, over allegations and proof (Verhandlungsmaxime), and second, over the subject matter (Dispositionsmaxime). The procedure was formalistic; its "articulated trial" prescribed a fixed order of steps needing to be taken by the parties at every procedural stage in line with the so-called positional procedure (Positionalverfahren) ${ }^{32}$.

The intricacy of the Roman-canonical procedure with its many interim judgments required the participation of professional judges and advocates proficient in both continental "learned laws". Moreover, from the $16^{\text {th }}$ century on the German local courts followed ever more frequently the practice of "dispatching the records of the case" (transmissio actorum or Aktenversendung) ${ }^{33}$. The records were sent to the law faculties of universities in order to obtain authoritative expert opinions issued by their committees (Spruchfakultäten), which the courts were obliged to follow ${ }^{34}$. The institution of Aktenversendung was abolished at the end of the $18^{\text {th }}$ century by the German territorial princes, but at the Reich-level only in 1879 .

\section{ACHIEVEMENTS OF MEDIEVAL CANON LAWYERS}

Bellum iustum. Both the conceptual framework and the ideas of power and organization, developed by medieval canon lawyers descended from Roman law, but the contents differed. In the realm of international law, the medieval theory of just war (bellum iustum) arose from the reflections of saint Augustine, Gratian, decretists, decretalists and Thomas

31 Raoul C. van Caenegem, "History of European Civil Procedure," in International Encyclopedia of Comparative Law, vol. XVI, ed. Mauro Cappelletti (Tübingen: Mohr Siebeck, The Hague, Paris: Mouton, New York: Oceana, 1973), 18.

32 Franz Wieacker, A History of Private Law in Europe with Particular Reference to Germany, trans. Tony Weir (Oxford: Clarendon Press, 1995), 139-140.

33 Peter Oestmann, "Gemeines Recht und Rechtseinheit," in Hierarchie, Kooperation und Integration im Europäischen Rechtsraum, ed. Eva Shumann (Berlin, Boston: Walter de Gruyter, 2015), 25-26.

34 Raoul C. van Caenegem, Judges, Legislators, Professors (Cambridge, New York: Cambridge University Press, 1987), 64-65. 
Aquinas $^{35}$. However, its broad formulation, embracing non-Christian peoples as well, was set forth at an early point by the Polish canonist of Cracow University, Paulus Vladimiri (Paweł Włodkowic 1370-1435), who represented Wladyslaw Jagiello, King of Poland and Grand Duke of Lithuania, in his contest against the Teutonic Knights at the Constance Council $(1414-1418)^{36}$.

The Poles were accused by the Ordo Teutonicum as "traitors" of Christianity who resorted to the military aid of Lithuanians, Samogitians, Tatars of the Golden Horde and other "infidels". The Knights justified their presence and territorial acquisitions in Lithuania and Poland by reference to the privileges of 1226 and 1245, granted to them apparently by Holy Roman Emperor Frederick II Hohenstaufen (1220-1250). In particular, it was alleged by the Knights that the emperor had given to them the lands of the Samogitians (Žemaitija), situated northwest of Lithuania: in fact, the conversion to Christianity of these enduringly pagan lands - the last remaining in Europe after Lithuania's conversion in 1387 - occurred only in $1413^{37}$.

However, Paulus Vladimiri replied to the charges of the Teutonic Knights with an argument borrowed directly from ancient Roman law, namely that nobody can dispose of an object he has no right to. Vladimiri, who cited in this context the ancient Roman principle nemo plus iuris ad alium transferre potest quam ipse haberet, ridiculed the old emperor, the last from the House of Hohenstaufen, who - liberalis in re aliena - purported to donate lands "which never belonged to him". Further, Vladimiri stressed, again invoking ancient Roman law, that the Teutonic Knights could have neither legally acquired these lands by prescription which in

35 Frederick H. Russell, The Just War in the Middle Ages (Cambridge: Cambridge University Press, 1975).

36 Tomasz Giaro, "Europa und das Pandektenrecht," Rechtshistorisches Journal 12 (1993): 335-36; Kenneth Pennington, "Between Naturalistic and Positivistic Concepts of Human Rights," in Vetera novis augere. Studia Wactaw Uruszczak, vol. II (Kraków: Jagiellonian University Press, 2010), 849-50; Wojciech Bańczyk, "The Right of Infidels to Protect their Goods," Ethical Perspectives 24.1 (2017): 39-58.

37 Stephen Christopher Rowell, Lithuania Ascending. A Pagan Empire within East-Central Europe, 1295-1345 (New York, Melbourne: Cambridge University Press, 1994). 
no case applies to goods violently taken, even if their previous holders were pagan $s^{38}$.

The final argument of Paulus Vladimiri seems to be the most striking: Christian faith never justifies the conversion of infidels by martial means which is expressly forbidden by canon law itself ${ }^{39}$. The infidels enjoy, in fact, the innate right to a peaceful life in their country. Vladimiri presented this stance in two writings: "A Treatise on the Power of the Pope and the Emperor against Infidels" (Tractatus de potestate papae et imperatoris respectu infidelium) and "Conclusions" (Opinio Hostiensis). In both works Vladimiri had anticipated the original rights of indigenous people which since the late Spanish scholastics were to become classical in the theory of public international law: the rights of just war, resistance, and religious freedom ${ }^{40}$.

In this way, Paulus Vladimiri may be considered an early forerunner of the doctrine of "peaceful coexistence" between Christian and pagan countries, officially acknowledged in public international law only by the late scholastic thinkers of the School of Salamanca, such as Dominicans Francisco Vitoria (1483-1546) and Bartolomé de las Casas $(1484-1566)^{41}$. The difference between Poland-Lithuania and the Ordo Teutonicum was not definitely resolved at the Constance Council. However, the Council debates brought a considerable success for Paulus Vladimiri whose ideas had to contend with the widespread condemnation of alliances with pagan peoples pursued to obtain military reinforcement against Christian enemies ${ }^{42}$.

38 Ludwik Ehrlich, ed., Works of Paul Vladimiri (a selection), vol. I (Warszawa: Instytut Wydawniczy Pax, 1968), 57-58, 81-83.

39 Tomasz Graff, "Servants of the Devil or Protectors of Christianity and Apostles Among Pagans?,” Folia Historica Cracoviensia 23 (2017): 143-176.

40 Loïc Chollet, "Paul Vladimir et le Ius Gentium polonais," Mémoires de la Société pour l'Histoire du Droit et des Institutions des anciens pays bourguignons, comtois et romands 69 (2012): 43-67.

41 Charles H. Alexandrowicz, The Law of Nations in Global History (Oxford: Oxford University Press, 2017), 51-61; Władysław Czapliński, "A Right of Infidels to Establish Their Own State?," in Religion and International Law. Living Together, ed. Robert Uerpmann-Wittzack et al. (Leiden, Boston: Brill Nijhoff, 2018), 37-56.

${ }^{42}$ Tomasz Widlak, "From Vladimiri's Just War to Kelsen's Lawful War. The universality of the bellum justum doctrine," Studia Philosophiae Christianae 53 (2017): 77-84. 
Marriage and family law. As a sacrament conferring the divine grace on the participants, marriage belonged to the matters spiritual (causae mere spirituales), whereas the residual family cases, such as engagement, dowry, and status, were considered mixed cases annexed to the spiritual ones (causae spiritualibus adnexae or mixtae). In consequence, from the $9^{\text {th }}$ to the $19^{\text {th }}$ centuries, marriage law in Europe was a dominating concern of canon law and, therefore, of the Church of Rome. The Church adopted the Roman principle "mutual consent makes the marriage" (consensus facit nuptias), which necessarily required, contrary to the old Germanic guardianship marriage (Muntehe), the consent of the woman.

In a clear departure from Roman law, which depended upon the continuous marital consent (affectio maritalis), canon law referred exclusively to the moment of the marriage's inception: matrimonium autem solo consensu contrahitur (Liber extra IV.1.14) ${ }^{43}$. Since the $12^{\text {th }}$ century, the woman's agreement was necessary, equally in the case of the Muntehe. Given that Christian marriage became a sacrament, it engendered a prohibition of divorce. In fact, this institution was replaced with a less radical separation "from bed and board", the original concept being "from table and bed" (a mensa et thoro). The separation reduced the duties of marriage without, however, dissolving it, and thus remarriage remained excluded ${ }^{44}$.

Freedom of contract. Freedom of contract was also developed first and foremost by the canonists and not by the medieval Romanists ${ }^{45}$. As against the classical Roman dichotomy of binding contractus and non-actionable agreements (pacta), which probably has its origins in the ritualistic nature of archaic Roman contract law, the canon lawyers applied the maxim pacta sunt servanda (agreements must be kept) to all pacts. Consequently, they

43 Stephan Meder, Rechtsgeschichte. Eine Einführung (Köln, Weimar, Wien: Böhlau, 2002), 127; Jan Zabłocki, "Consensus facit nuptias," in Marriage. Ideal - Law - Practice, ed. Zuzanna Służewska and Jakub Urbanik (Warsaw: The Raphael Taubenschlag Foundation, 2005), 245-247.

44 James A. Brundage, Law, Sex, and Christian Society in Medieval Europe (Chicago, London: The University of Chicago Press, 1987), 370-376, 453-458; Helmholz, The Spirit, 240-242.

45 Piotr Alexandrowicz, Kanonistyczne uzasadnienie swobody umów w zachodniej tradycji prawnej (Poznań: Wydawnictwo Naukowe UAM, 2020). 
were, without more, to be considered "clothed" (pacta vestita). They were described in this way in recognition of the fact that they became actionable and therefore treated on par with traditional contracts attended by a valid ground or basis (causa) for their enforcement ${ }^{46}$.

In contrast to ancient Roman law, which required the enduring intention to remain married (affectio maritalis), medieval canon law had regard only to the consent of the couple in the moment at which the marriage was contracted (Liber extra IV.1.14 solo consensu contrahitur). Furthermore, the example of Roman marriage law, ruled by the proverb "agreement and not copulation creates marriage" (Ulp. D. 50.17 .30 nuptias non concubitus, sed consensus facit), engendered the tendency in medieval private law doctrine towards the assumption that all contracts are necessarily grounded on consent. Moreover, according to the maxim solus consensus obligat, consent alone was sufficient to conclude a contract.

In this way, during the Late Middle Ages, the old requirement that contracts be matched to a closed list of types, which was the precondition to their enforcement in ancient Roman law, was gradually overcome. Under the influence of, first, canon lawyers and, subsequently, natural law scholars, there emerged and became dominant the diametrically opposed doctrine of the enforceability of all agreements, concluded with or without valid grounds (causa), as well as with or without usual form ${ }^{47}$. Within the German Reich, the principle "a promise is a promise" (ein Mann, ein Wort) supported the canon lawyers in pruning away contract formalities which were previously required in the Frankish Kingdoms.

From out of the paradigm of freedom of contract there had to emerge in medieval legal scholarship, sooner or later, the question of its limits. These were mostly connected with problems of contractual equality and contractual justice ${ }^{48}$. Their fair solution required a moral inquiry into

46 Łukasz Korporowicz, "Pacta sunt servanda w prawie kanonicznym," in Pacta sunt servanda: nierealny projekt czy gwarancja tadu spotecznego i prawnego?, ed. Ewa Kozerska et al. (Kraków: AT Wydawnictwo, 2015), 113-125.

${ }^{4}$ Meder, Rechtsgeschichte, 131-134; Roberto Fiori, "The Roman Conception of Contract," in Obligations in Roman Law. Past, Present, and Future, ed. Tomas A.J. McGinn (Ann Arbor: The University of Michigan Press, 2012), 66.

48 James Gordley, Foundations of Private Law. Property, Tort, Contract, Unjust Enrichment (Oxford: Oxford University Press, 2006), 361-376. 
the content of contract agreed upon in order to ensure some kind of material equivalence between performance and counter-performance. This inquiry, started already by the ancient Church Fathers, was furthered by medieval civilians and canonists from the school of commentators who, in early modern times, were followed in this endeavour and eventually substituted by natural-law thinkers.

Obviously we must acknowledge that the traces of the institution of fair price (iustum pretium), negatively mirrored by unfair advantage (laesio enormis), had backwardly emerged already in the framework of the contract of sale practiced at the threshold of the Later Roman Empire ${ }^{49}$. However, by the lawyers of the $14^{\text {th }}$ and the early $15^{\text {th }}$ century the problem of equality in exchange was considered from a wider perspective than that of the ancient Roman law. In particular, inspired by saint Augustine and the Decretum (C. 22, q. 2, c. 14), they extended the requirement of contractual equality to situations in which since the contract's conclusion an unexpected change of circumstances had intervened (clausula rebus sic stantibus) ${ }^{50}$.

Successions. In the law of successions, the medieval canonists, following the ancient Fathers of the Church, promoted energetically the testamentary inheritance, i.e. inheritance under will, as against inheritance on intestacy. Notably they promoted the institution of the so-called soul-portion (Seelteil of the Germanic law) or God's portion ${ }^{51}$. It was the portion amounting to one third of the inheritance free from relatives' rights and properly assigned to the benefit of the Christian Church alone. In this

49 Aleksander Grebieniow, Rechtsfolgen der Übervorteilung. Eine rechtsvergleichende Untersuchung der modernen Figuren der laesio enormis (Zürich, Basel, Genf: Schulthess 2015), 16-20.

50 Tomasz Giaro, Excusatio necessitatis nel diritto romano (Warszawa: Wydawnictwa Uniwersytetu Warszawskiego, 1982), 24-25, 194-195; Reinhard Zimmermann, The Law of Obligations. Roman Foundations of the Civilian Tradition (Cape Town, Wetton, Johannesburg: Juta \& Co., 1990), 579-582; Andreas Thier, "Legal History," in Unexpected Circumstances in European Contract Law, ed. Ewoud Hondius and Hans C. Grigoleit (Cambridge: Cambridge University Press, 2011), 15-32.

51 Eberhard Friedrich Bruck, "Kirchenväter und Seelteil," Zeitschrift der Savigny-Stiftung Romanistische Abteilung 72 (1955): 191-210; Harold J. Berman, Law and Revolution, vol. I (Cambridge MA, London: Harvard University Press, 1983), 230-231. 
respect, the local German laws, first and foremost that of Saxony, offered fierce resistance since the jurymen (Schöffen) of the city of Magdeburg even in the $14^{\text {th }}$ century still remained reluctant to accept the will as a proper legal institution.

Although generally the dying meditate upon the soul's salvation more eagerly than the living, the Church was benefitted in like manner by means of a simple transaction inter vivos, designated as gift "for the (salvation of the) soul" (donatio pro anima, pro remedio or pro salute animae) ${ }^{52}$. This institution, known already in the $7^{\text {th }}$ to the $9^{\text {th }}$ centuries, was strictly connected to almsgiving, in line with the supposition that the donated goods did not belong to bishops, but directly to the poor ${ }^{53}$. The extended family grouping offered no noteworthy opposition, since from the $12^{\text {th }}$ century on, its importance declined. The wider kindred, whether related through husband or wife, remained relevant only in cases of transfer of immovables.

Juristic personality. Of special note is the contribution of the medieval canonists to the institution of the legal person. Whereas corporate bodies remained a comparative rarity in lay society, within the structure of the medieval Church they were present at every level. Probably, the origin of these developments relies in the early medieval monastic communities which were considered as self-governing and autonomous. However, the sharp division between the Church and secular rulers introduced by the Papal Revolution, initiated by Pope Gregory VII in the mid- $11^{\text {th }}$ century, drove the re-conceptualization of the whole Church as one public "corporation of the faithful" (universitas fidelium) or "body of Christians" (corpus Christianorum) $)^{54}$.

52 Raoul C. van Caenegem, An Historical Introduction, 185; Eliana Magnani, "Le don au Moyen Age. Pratique sociale et représentations. Perspectives de recherche," Revue du Mauss 19 (2002): 311-314.

53 Eliana Magnani, "Almsgiving, Donatio Pro Anima and Eucharistic Offering in the Early Middle Ages," in Charity and Giving in Monotheistic Religions, ed. Miriam Frenkel and Yaacov Lev (Berlin, New York: Walter De Gruyter, 2009), 111-121.

54 James A. Brundage, Medieval Canon Law (London, New York: Pearson Education, 1995), 19-21, 99-105. 
By 1200 , the canon lawyers could already distinguish clearly between natural and juristic persons which meant that in a particular case the holder of an office had to be considered as clearly distinct from the office itself ${ }^{55}$. Concerning the identity of the juristic person, the canonists inclined with Sinibaldo dei Fieschi, later pope Innocent IV, toward the fiction doctrine (persona ficta) which in the $19^{\text {th }}$ century came to be partially adopted by the great Romanist Savigny, and subsequently rejected by the Germanist Gierke with his concept of the "real associative person"56. During the Late Middle Ages, private corporations endowed with legal personality emerged, having as their object the common exploitation of mines, quarries and mills ${ }^{57}$.

Constitutional law. There are also examples of some influence exercised by medieval canon law on contemporary constitutional law. Meditating upon this topic, the today's jurist must take into consideration that the medieval Church of Rome was not a purely religious undertaking in the modern meaning. It was rather an all-embracing institution of social governance assuring the authoritative guidance aimed at rebuilding the whole society in the new, Christian sense. In this framework the Church disposed, from a technical point of view, not only of the monarchic model of papacy powers, but also of an alternative "democratic" model of decision making which at an early stage can be defined as synodal and later as conciliar ${ }^{58}$.

Let us consider some aspects of the constitutional law of the medieval Church which did not remain without historical consequences. First,

55 Ernst H. Kantorowicz, The King's Two Bodies. A Study in Mediaeval Political Theology (Princeton: Princeton University Press, 1957), passim.

56 AA. VV., La persona giuridica collegiale in diritto romano e canonico, ed. Onorio Bucci and Tarcisio Bertone (Città del Vaticano: Libreria editrice vaticana, 1990); Tomasz Giaro, "Krótka historia istoty osoby prawnej," in Consul est iuris et patriae defensor (Warszawa: Ministerstwo Spraw Zagranicznych, 2012), 65-68.

57 Germain Sicard, Aux origines des sociétés anonymes. Les moulins de Toulouse au Moyen Age (Paris: Armand Colin, 1953).

58 Walter Ullmann, Law and Politics in the Middle Ages. An Introduction to the Sources of Medieval Political Ideas (Cambridge: Cambridge University Press 1975), 40-41, 120-121, 151-152. 
Bernhard of Pavia (Papiensis) in his Summa de electione and other canonists analyzed electoral law as early as the late $12^{\text {th }}$ century. In this framework, the requirement of the consent of all interested parties according to the misinterpreted Roman rule "what touches all, must be approved by all" (Liber sextus V.13.29 quod omnes tangit debet ab omnibus approbari) mutated almost imperceptibly into the principle of majority decision in line with the saying pars maior pars sanior ${ }^{59}$. The latter found application in the obligatory two-thirds majority required since 1179 for pope elections ${ }^{60}$.

In the second place, legal historians adduce the medieval theory of representation, and specifically its influence on the practices that have come to constitute modern representative government, representative constitutional ordering, and representative democracy ${ }^{61}$. Admittedly, the term repraesentatio was known to ancient Roman lawyers, but the legal institution itself was developed only by the medieval canonists. In fact, the Church of Rome even allowed the establishment of a relationship as strictly personal as marriage by representatives (per procura). From the $14^{\text {th }}$ century on, corporatism, and particularly conciliarism, flourished within the Church; the next historical steps were constitutionalism and parliamentarism ${ }^{62}$.

Finally, in reference to the current public administration system, mention must be made of the medieval institutions of territorial self-governance. These institutions of local democracy were rooted not only in the tradition of the late medieval municipalities (communes) of Central and Northern Italy, but also in the much older ancient tradition of self-organization of the monastic communities and monasteries in the times of the early Christian Church. The Church was traditionally an autonomous social organization which during the High Middle Ages became able to

59 Wacław Uruszczak, "Reguła quod omnes tangit debet ab omnibus approbari," in id., Opera, 485-487.

60 Peter Landau, "Der Einfluss des kanonischen Rechts auf die europäische Rechtskultur," in Europäische Rechts- und Verfassungsgeschichte, ed. Reiner Schulze (Berlin: Duncker \& Humblot, 1991), 49-50; Jasmin Hauck, "Quod omnes tangit debet ab omnibus approbari,” Zeitschrift der Savigny-Stiftung Kanonistische Abteilung 130 (2013): 412-413.

${ }_{61}$ Tierney, Church Law; Jan Baszkiewicz, Myśl polityczna wieków średnich (Poznań: Wydawnictwo Poznańskie, 2009), 130-137.

62 Joseph Canning, A History of Medieval Political Thought 300-1450 (London, New York: Routledge 1996), 174-184; Lesaffer, European Legal History, 218-221. 
include and apply many elements and mechanisms of corporate self-government. These were then transmitted by clerics as "officials of the law" 63 to lay polities.

\section{HISTORICAL SIGNIFICANCE OF MEDIEVAL CANON LAW}

The first transnational law. The historical significance of medieval canon law consists not only in its multifarious contributions to modern substantive and procedural law, public and private, but also in its modern form. In what precisely does this modernity of medieval canon law consist? Above all, its modern character is evident in its being the first - to apply a current term - 'trans-national' law in history. Admittedly, the concept of transnational law was first formulated by Philip Caryl Jessup, an American judge of the International Court of Justice in the Hague, in his monograph published in 1956 under the same title ${ }^{64}$. But canon law was a supra-territorial and, in this sense, trans-national system already during the Middle Ages ${ }^{65}$.

Usually, the place of honour in this respect is awarded by European legal historians, rather wrongly than rightly, to medieval commercial law recognized as the "law merchant" or, in Latin, the lex mercatoria or ius mercatorum $^{66}$. As a matter of fact, the medieval canon law was, at least in its intention, neither supranational nor international, but nonetheless it was considered binding by all the faithful without regard to their citizenship, nationality or subjection to any state power. The modern American canon lawyer, Kenneth Pennington, in some circumstances went even so far as to

63 Brundage, The Medieval Origins, 73-74.

64 Philip Caryl Jessup, Transnational Law (New Haven: Yale University Press, 1956).

65 Tomasz Giaro, "Transnational Law and its Historical Precedents," Studia Iuridica 68 (2016): 73-85.

66 Ralf Michaels, "Response. Legal Medievalism in Lex Mercatoria Scholarship," Texas Law Review 90 (2012): 259-268, id., "The True Lex Mercatoria: Law Beyond the State," Indiana Journal of Global Legal Studies 14.2 (2007): 452-468. 
attribute this transnational quality to the whole body of the European ius commune, consisting as utrumque ius of both civil and canon law ${ }^{67}$.

So, it is clear that the territorial extension of medieval and early modern Christianity (Respublica Christianorum) exceeded by far the borders of the Holy Roman Empire, where Roman law was effective as the law of the ruler. Hence, the first scholar to associate Roman law with (merely continental) Europe as a relatively homogeneous legal area, Paul Koschaker, committed in his renown monograph Europa und das römische Recht, published in $1947^{68}$, the banal error of taking a part for the whole. In fact, the Western legal tradition was based, in its entirety, not on Roman, but rather on canon law; embracing the common law of England, this tradition represented - to cite Harold Joseph Berman - a "transnational legal culture"69.

Origins of commercial law. Canon law influenced medieval trade as well. The juristic crux was here the prohibition of lending at interest, censured by the Church as the sin (peccatum) of usury. The ban descended from Jewish law with its prescription "lend, expecting nothing back" (Luke 6.35 mutuum date nibil inde sperantes), as well as from Roman law which classified the contract of loan (mutuum) as necessarily gratuitous. So, in 1179, Pope Alexander III threatened every usurer with excommunication, and in 1215 Innocent III censured the Jews for taking interest ${ }^{70}$. Moreover, in 1236 Gregory IX condemned Roman sea loans as usurious, and Clement V declared in 1311 any secular law allowing usury as void.

However, medieval legal doctrine found always new avenues for evasion, transforming the canon law of usury at the end - this is Harold Joseph Berman's conclusion - in "a system of exceptions to the prohibition against usury" ${ }^{\text {"11 }}$. Some of them were already known to ancient Roman law,

${ }^{67}$ Kenneth Pennington, "Sovereignty and Rights in Medieval and Early Modern Jurisprudence," in Studies in Honour of Wiestaw Litewski, vol. II, ed. Janusz Sondel et al. (Kraków: Jagiellonian University Press, 2003), 26-27.

68 Paul Koschaker, Europa und das römische Recht (München: Biederstein, 1947).

69 Berman, Law and Revolution, 11.

70 John Henry A. Munro, “The Medieval Origins of the Financial Revolution,” International History Review 25 (2003): 507-509.

71 Berman, Law and Revolution, 249. 
such as the transfer of a thing with an authorization to sell it and keep the realized price as a loan (contractus mohatrae), as well as the giving of a thing in payment (datio in solutum $)^{72}$, others were vigorously developed by the juristic interpretation only during the High and Late Middle Ages. In this framework emerged most notably the early forms of limited commercial partnership (commenda), the bill of exchange (cambium), and marine insurance.

The commenda contract had its origins - except some Muslim influences - in the Northern Italian city-states of Venice and Genoa during the $12^{\text {th }}$ century. The name commenda stems from entrusting, that is the 'commending' (commendare), of a certain amount of money to a travelling partner (commendatarius) who acted as business agent. From him the sedentary financing partner (commendator) demanded not interest, which was forbidden by canon law, but merely the sharing of the profit or loss arising out of this commercial voyage, which was allowed ${ }^{73}$. Subsequently, the shares of the limited commercial partnership became documented and transferable, determining precisely the extent of liability of each partner.

The bill of exchange (cambium), "the most important financial innovation of the High Middle Ages"74, was originally a written informal order directed by a merchant to a foreign business contact, or to the merchant's agent-banker in some other city. The order required that the latter pay a sum of money to another merchant on behalf of the merchant who had given the order ${ }^{75}$. This operation, known in Central-Northern Italy as early as the end of the $12^{\text {th }}$ century, allowed to avoid the cost and risk of money transport. The bill of exchange became an important negotiable instrument, since in calculating the exchange rate a certain surcharge was tolerated by canon law as a kind of premium for the exchange effort ${ }^{76}$.

72 Zimmermann, The Law of Obligations, 162-163, 170-172, 753-754.

73 John H. Pryor, "The Origins of the Commenda Contract," Speculum 52 (1977): 5-37.

74 Edwin S. Hunt and James M. Murray, A History of Business in Medieval Europe 1200-1550 (Cambridge: Cambridge University Press, 1999), 65.

75 Abbot Payson Usher, "The Origin of the Bill of Exchange," Journal of Political Economy 22 (1914): 566-576.

76 Jared Rubin, "Bills of Exchange, Interest Bans, and Impersonal Exchange in Islam and Christianity," Explorations in Economic History 47 (2010): 215-221. 
Finally, we must take into consideration the sea or marine insurance. This "elder brother to all other insurance" 77 appeared in the late $13^{\text {th }}$ and early $14^{\text {th }}$ centuries in several republican city-states of Northern Italy, allowing the insurer to collect interest in the guise of a premium interpreted as counter-performance for the insurer's assumption of risk ${ }^{78}$. Insofar as sea insurance was functionally a successor to the forbidden ancient Roman sea loan, called fenus nauticum or pecunia traiecticia, the latter institution came to disappear from the global market of financial instruments, albeit this occurred on account of competing commercial developments which took the form of more sophisticated contracts of marine insurance.

Aspects of soft law. Medieval canon law was not only the first transnational law in legal history; it was also the first legal system to make extensive use of many instruments of legal communication which today would be considered typical elements of so-called soft law, rather than classic commands in imperative form. Most legal encyclopedias and dictionaries state and most of their readers gladly believe that soft law was invented by the British jurist Lord McNair sometime in the $1970 \mathrm{~s}^{79}$. However, a species of law consisting of numerous non-mandatory normative speech acts, such as recommendations, admonitions, exhortations, and counsels of advice (consilia), was already manifest in the canon law of medieval times ${ }^{80}$.

Although this law, being a legal system of transnational type, could not make a direct use of the coercive apparatus of a "national" state avant la lettre or of other kind of polity, we must take into consideration the whole richness of legal instruments and factual remedies being at the disposal of

77 C. Bradford Mitchell, A Premium on Progress. An Outline History of the American Marine Insurance Market (New York: The Newcomen Society in North America, 1970), 9.

78 Florence Edler de Roover, "Early Examples of Marine Insurance," The Journal of Economic History 5 (1945): 172-200; Sebastian Lohsse, "Vom Seedarlehen zur Versicherung in der mittelalterlichen Rechtswissensachaft," Zeitschrift der Savigny-Stiftung Romanistische Abteilung 133 (2016): 372-399.

79 Tomasz Giaro, "Dal soft law moderno al soft law antico," in Soft law e hard law nelle società postmoderne, ed. Alessandro Somma (Torino: Giappichelli, 2009), 83-84.

${ }_{80}$ Norberto Bobbio, "Comandi e consigli," in Raccolta di scritti in onore di Arturo Carlo Jemolo, vol. IV (Milano: Giuffrè, 1963), 75. 
the Church. This is exactly what is alluded to by the famous paradoxical dictum of an outstanding British legal historian, Frederic William Maitland: "the medieval Church was a State" 11 . Nevertheless, in spite of their frequently optional nature, the rules of canon law, equal for all subjects, were followed - and are followed to this day - because Christians accepted the authority of the religious office from which they emanated.

Modern codifications. Canon law could not avoid the problems inherent in the modern phenomenon of codification. So, the old compilation of ancient and medieval canonical sources, the Corpus Iuris Canonici of 1582, remained in force only until 1917, when it was replaced by the Codex Iuris Canonici of Pope Benedict XV. Yet, during the pontificate of John Paul II in the wake of the Second Vatican Council (1962-65), a new codex, which is still in force, was promulgated in 1983. Interestingly, as far as lending at interest is concerned, the former code allowed it, excluding only an "immoderate" rate of interest (can. 1543), but in the latter code the medieval anti-usury stance of the Church is not even mentioned ${ }^{82}$.

At the same time, even if each codification adopted had to be regarded as containing the new law presently in force, the canonists cultivated the virtue of continuity, which is so characteristic of their legal thinking ${ }^{83}$. In marked contrast to the schemes of continental private law, whose successive codifications purport to present several novelties and, first and foremost, a new systematization of the matter, canon law disavows such intentions. Usually, old sources of canon law remain in force despite the advent of new codifications. Thus, the code of 1917 provided explicitly (can. 6, n. 2) that the canons containing the old law (ius vetus) should continue to be interpreted according to their former way of interpretation ${ }^{84}$.

81 Frederic William Maitland, Roman Canon Law in the Church of England (London: Methuen, 1898), 100; cf. Giaro, Transnational Law, 77.

82 Angelo Riccio, Il contratto usurario nel diritto civile (Padova: Cedam, 2002), 13-14.

83 Paolo Grossi, A History of European Law (Chichester: Wiley-Blackwell, 2010), $135-137$.

${ }^{84}$ Franciszek Longchamps de Berier, "Wobec dekodyfikacji: tradycja romanistyczna i prawo kanoniczne," Acta Universitatis Wratislawiensis. Prawo 305 (2008): 183-187. 


\section{REFERENCES}

AA. VV, La persona giuridica collegiale in diritto romano e canonico, edited by Onorio Bucci, and Tarcisio Bertone. Città del Vaticano: Libreria editrice vaticana, 1990.

Alexandrowicz, Charles H. The Law of Nations in Global History. Oxford: Oxford University Press, 2017.

Alexandrowicz, Piotr. Kanonistyczne uzasadnienie swobody umów w zachodniej tradycji prawnej. Poznań: Wydawnictwo Naukowe UAM, 2020.

Bańczyk, Wojciech. "The Right of Infidels to Protect their Goods from the Perspective of the $15^{\text {th }}$ Century Polish School of Ius gentium." Ethical Perspectives 24.1 (2017): 39-58.

Baszkiewicz, Jan. Myśl polityczna wieków średnich. Poznań: Wydawnictwo Poznańskie, 2009.

El Beheiri, Nadja. "Der Einfluss des Sachsenspiegels auf die Entwicklung des ungarischen Rechts im Mittelalter." In Sachsen im Spiegel des Rechts. Ius Commune Propriumque, edited by Adrian Schmidt-Recla, Eva Schumann, and Frank Theisen, 79-93. Köln, Weimar, Wien: Böhlau Verlag, 2001.

Bellomo, Manlio. The Common Legal Past of Europe 1000-1800. Washington DC: The Catholic University of America Press, 1995.

Berman, Harold J. Law and Revolution. The Formation of the Western Legal Tradition. Cambridge MA, London: Harvard University Press, 1983.

Bobbio, Norberto. "Comandi e consigli." In Raccolta di scritti in onore di Arturo Carlo Jemolo, vol. IV. Filosofia del Diritto, Storia del Diritto, 75-98. Milano: Dott. Antonino Giuffrè Editore, 1963.

Brown, Peter. The Rise of Western Christendom. Triumph and Diversity AD 200-1000. Malden MA, Oxford: Blackwell Publishers, 1998.

Bruck, Eberhard Friedrich. "Kirchenväter und Seelteil." Zeitschrift der Savigny-Stiftung Romanistische Abteilung 72 (1955): 191-210.

Brundage, James A. Law, Sex, and Christian Society in Medieval Europe. Chicago, London: The University of Chicago Press, 1987.

Brundage, James A. Medieval Canon Law. London, New York: Pearson Education Ltd., 1995.

Brundage, James A. The Medieval Origins of the Legal Profession. Canonists, Civilians, and Courts. Chicago, London: The University of Chicago Press, 2008.

Bussi, Emilio. La formazione dei dogmi di diritto privato nel diritto comune. vol. I. Diritti reali e diritti di obbligazione. Padova: Cedam Casa Editrice Dott. Antonio Milani, 1937. 
Caenegem, Raoul C. van. An Historical Introduction to Private Law. Cambridge, New York, Melbourne: Cambridge University Press, 1992.

Caenegem, Raoul C. van. "History of European Civil Procedure." In International Encyclopedia of Comparative Law, vol. XVI. Civil Procedure, edited by Mauro Cappelletti, 1-114. Tübingen: Mohr Siebeck, The Hague, Paris: Mouton, New York: Oceana Publications Inc., 1973.

Caenegem, Raoul C. van. Judges, Legislators, Professors. Chapters in European Legal History. Cambridge, New York: Cambridge University Press, 1987.

Chollet, Loïc. "Paul Vladimir et le Ius Gentium polonais: un droit de résistance au début du XVème siècle?." Mémoires de la Société pour l'Histoire du Droit et des Institutions des anciens pays bourguignons, comtois et romands 69 (2012): 43-67. Czapliński, Władysław. "A Right of Infidels to Establish Their Own State? Remarks on the Writing of Paulus Vladimiri and Francisco de Vitoria." In Religion and International Law. Living Togehther, edited by Robert Uerpmann-Wittzack et al., 37-56. Leiden, Boston: Brill Nijhoff, 2018.

Dębiński, Antoni. Church and Roman Law. Lublin: Wydawnictwo KUL, 2010. Ebel, Friedrich, and Georg Thielmann. Rechtsgeschichte. Ein Lehrbuch, vol. I. Antike und Mittelalter. Heidelberg: C.F. Müller Juristischer Verlag GmbH, 1989. Edler de Roover, Florence M. "Early Examples of Marine Insurance." The Journal of Economic History 5 (1945): 172-200.

Ehrlich, Ludwik, ed. Works of Paul Vladimiri (a selection) = Pisma wybrane Pawta Wtodkowica, vol. I. Warszawa: Instytut Wydawniczy Pax, 1968.

Fiori, Roberto. "The Roman Conception of Contract." In Obligations in Roman Law. Past, Present, and Future, edited by Tomas A.J. McGinn, 40-75. Ann Arbor: The University of Michigan Press, 2012.

Fögen, Marie Theres. "Das Politische Denken der Byzantiner." In Pipers Handbuch der politischen Ideen, vol. II, edited by Iring Fetscher, and Herfried Münkler, 41-85. München, Zürich: Piper Verlag, 1993.

Giaro, Tomasz. "Dal soft law moderno al soft law antico." In Soft law e hard law nelle società postmoderne, edited by Alessandro Somma, 83-99. Torino: G. Giappichelli Editore, 2009.

Giaro, Tomasz. "Europa und das Pandektenrecht." Rechtshistorisches Journal 12 (1993): 326-345.

Giaro, Tomasz. "Europejska geneza polskich zasad i wartości konstytucyjnych.” Państwo Prawne 3 (2013): 7-17.

Giaro, Tomasz. Excusatio necessitatis nel diritto romano. Warszawa: Wydawnictwa Uniwersytetu Warszawskiego, 1982. 
Giaro, Tomasz. "Krótka historia istoty osoby prawnej." In Consul est iuris et patriae defensor. Ksiega pamiątkowa dedykowana doktorowi Andrzejowi Kremerowi, 59-74. Warszawa: Ministerstwo Spraw Zagranicznych, 2012.

Giaro, Tomasz. "Legal Historians and the Eastern Border of Europe." In Methodenfragen der Romanistik im Wandel. Paul Koschakers Vermächtnis, edited by Tommaso Beggio, and Aleksander Grebieniow, 145-162. Tübingen: Mohr Siebeck, 2019.

Giaro, Tomasz. "Transnational Law and its Historical Precedents." Studia Iuridica 68 (2016): 73-85.

Gordley, James. Foundations of Private Law. Property, Tort, Contract, Unjust Enrichment. Oxford: Oxford University Press, 2006.

Gordley, James. The Jurists. A Critical History. Oxford: Oxford University Press, 2013.

Graff, Tomasz. "Servants of the Devil or Protectors of Christianity and Apostles among Pagans? Shaping the image of Poland and Poles in the context of steps taken by Wladyslaw II Jagiello's diplomacy." Folia Historica Cracoviensia 23 (2017): 143-176.

Grebieniow, Aleksander. Rechtsfolgen der Übervorteilung. Eine rechtsvergleichende Untersuchung der modernen Figuren der laesio enormis und ihren historischen Grundlagen. Zürich, Basel, Genf: Schulthess, 2015.

Grodecki, Roman. Sprawa św. Stanistawa. Wydawnictwo Literackie: Kraków, 1979.

Grossi, Paolo. A History of European Law. Chichester: Wiley-Blackwell, 2010.

Hattenhauer, Hans. Europäische Rechtsgeschichte, $2^{\text {nd }}$ ed. Heidelberg: C.F. Müller Juristischer Verlag GmbH, 1994.

Hauck, Jasmin. "Quod omnes tangit debet ab omnibus approbari - Eine Rechtsregel im Dialog der beiden Rechte." Zeitschrift der Savigny-Stiftung Kanonistische Abteilung 130 (2013): 398-417.

Helmholz, Richard Henry. The Spirit of Classical Canon Law. Athens Georgia: The University of Georgia Press, 1996.

Hunt, Edwin S., and James M. Murray. A History of Business in Medieval Europe, 1200-1550. Cambridge: Cambridge University Press, 1999.

Jessup, Philip Carlyle. Transnational Law. New Haven: Yale University Press, 1956.

Kaiser, Wolfgang. Authentizität und Geltung spätantiker Kaisergesetze. Studien zu den Sacra privilegia concilii Vizaceni. München: Verlag C.H. Beck, 2007.

Korporowicz, Łukasz Jan. "Roman Law Behind the Decrees 39-41 of the Fourth Lateran Council." In The Fourth Lateran Council and the Development of Can- 
on Law and the ius commune, edited by Atria A. Larson et al., 235-250. Turnhout: Brepols, 2018.

Korporowicz, Łukasz Jan. "Pacta sunt servanda w prawie kanonicznym.” In Pacta sunt servanda: nierealny projekt czy gwarancja tadu spotecznego i prawnego?, edited by Ewa Kozerska et al., 113-125. Kraków: AT Wydawnictwo, 2015.

Koschaker, Paul. Europa und das römische Recht. München: Biederstein, 1947.

Kriechbaum, Maximiliane. "Die Zuständigkeiten der kirchlichen Gerichte im Spiegel der Legistik.” Glossae. European Journal of Legal History 13 (2016): 342-370.

Landau, Peter. "Der Einfluss des kanonischen Rechts auf die europäische Rechtskultur." In Europäische Rechts- und Verfassungsgeschichte. Ergebnisse und Perspektiven der Forschung, edited by Reiner Schulze, 39-57. Berlin: Duncker \& Humblot, 1991.

Landau, Peter. "Gratian and the Decretum Gratiani." In The History of Medieval Canon Law in the Classical Period, 1140-1234. From Gratian to the Decretals of Pope Gregory IX, edited by Wilfried Hartmann, and Kenneth Pennington, 22-54. Washington DC: The Catholic University of America Press, 2008.

Lange, Hermann, and Maximiliane Kriechbaum. Römisches Recht im Mittelalter, vol. II. Die Kommentatoren. München: Verlag C.H. Beck, 2007.

Lesaffer, Randall. European Legal History. A Cultural and Political Perspective. Cambridge, New York: Cambridge University Press, 2009.

Litewski, Wiesław. Der römisch-kanonische Zivilprozess nach den älteren ordines iudiciarii, vol. I. Kraków: Jagiellonian University Press, 1999.

Lohsse, Sebastian. "Vom Seedarlehen zur Versicherung in der mittelalterlichen Rechtswissenschaft." Zeitschrift der Savigny-Stiftung Romanistische Abteilung 133 (2016): 372-399.

Longchamps de Berier, Franciszek. "Wobec dekodyfikacji: tradycja romanistyczna i prawo kanoniczne." Acta Universitatis Wratislaviensis. Prawo 305 (2008): 179-188.

Magnani, Eliana. "Almsgiving, Donatio Pro Anima and Eucharistic Offering in the Early Middle Ages of Western Europe (4th - 9th century)." In Charity and Giving in Monotheistic Religions, edited by Miriam Frenkel, and Yaacov Lev, 111-121. Berlin, New York: Walter De Gruyter, 2009.

Magnani, Eliana. "Le don au Moyen Age. Pratique sociale et représentations. Perspectives de recherche." Revue du Mauss 19 (2002): 309-322.

Maitland, Frederic William. Roman Canon Law in the Church of England. Six Essays. London: Methuen \& Co., 1898.

Massironi, Andrea. "Prescrizione e buona fede acquisitiva: la costituzione Quoniam omne (c.41) nell'interpretazione della canonistica medievale." In The Fourth 
Lateran Council and the Development of Canon Law and the ius commune, edited by Atria A. Larson et al., 251-279. Turnhout: Brepols, 2018.

Meder, Stephan. Rechtsgeschichte. Eine Einführung. Köln, Weimar, Wien: Böhlau Verlag, 2002.

Michaels, Ralf. "Response. Legal Medievalism in Lex Mercatoria Scholarship." Texas Law Review 90 (2012): 259-268.

Michaels, Ralf. “The True Lex Mercatoria: Law Beyond the State.” Indiana Journal of Global Legal Studies 14.2 (2007): 447-468.

Mitchell, C. Bradford. A Premium on Progress. An Outline History of the American Marine Insurance Market, 1820-1970. New York: The Newcomen Society in North America, 1970.

Munro, John Henry A. "The Medieval Origins of the Financial Revolution. Usury, Rents, and Negotiability." International History Review 25 (2003): 505-562.

Oestmann, Peter. "Gemeines Recht und Rechtseinheit." In Hierarchie, Kooperation und Integration im Europäischen Rechtsraum. 17. Symposion der Kommission Die Funktion des Gesetzes in Geschichte und Gegenwart, edited by Eva Shumann, 1-49. Berlin, Boston: Walter de Gruyter, 2015.

Pennington, Kenneth. "Between Naturalistic and Positivistic Concepts of Human Rights." In Vetera novis augere. Studia i prace dedykowane Profesorowi Wactawowi Uruszczakowi, vol. II, 845-851. Kraków: Jagiellonian University Press, 2010.

Pennington, Kenneth. "Sovereignty and Rights in Medieval and Early Modern Jurisprudence: Law and Norms without a State." In Roman Law as Formative of Modern Legal Systems. Studies in Honour of Wiestaw Litewski, edited by Janusz Sondel et al., vol. II, 25-36. Kraków: Jagiellonian University Press, 2003.

Pennington, Kenneth. "Western Legal Collections in the Twelfth and Thirteenth Centuries." In Religious Minorities in Christian, Jewish and Muslim Law (5th-15th Centuries), edited by Nora Berend, Youna Hameau-Masset et al., 77-98. Tournhout: Brepols Publishers, 2017.

Pryor, John H. "The Origins of the Commenda Contract." Speculum 52 (1977): $5-37$.

Rhee, Cornelis H. van. "English and Continental Civil Procedure. Similarities Today and in the Past." In Studies in Honour of Wiestaw Litewski, vol. II, edited by Janusz Sondel et al., 201-216. Kraków: Jagiellonian University Press, 2003. Riccio, Angelo. Il contratto usurario nel diritto civile. Padova: Cedam Casa Editrice Dott. Antonio Milani, 2002.

Robinson, Olivia F., T. David Fergus, and William M. Gordon. European Legal History. Sources and Institutions, $3^{\text {rd }}$ ed. London, Edinburgh, Dublin: Butterworths, 2000. 
Rowell, Stephen Christopher. Lithuania Ascending. A Pagan Empire within East-Central Europe 1295-1345. New York, Melbourne: Cambridge University Press, 1994.

Rubin, Jared. "Bills of Exchange, Interest Bans, and Impersonal Exchange in Islam and Christianity." Explorations in Economic History 47 (2010): 213-227.

Russell, Frederick H. The Just War in the Middle Ages. Cambridge: Cambridge University Press, 1975.

Schlosser, Hans. Grundzüge der Neueren Privatrechtsgeschichte. Ein Studienbuch, $8^{\text {th }}$ ed. Heidelberg: C.F. Müller Juristischer Verlag GmbH, 1996.

Schrage, Eltjo J.H. Utrumque Ius. Eine Einführung in das Studium der Quellen des mittelalterlichen gelehrten Rechts. Berlin: Duncker \& Humblot, 1992.

Sicard, Germain. Aux origines des sociétés anonymes. Les moulins de Toulouse au Moyen Age. Paris: Armand Colin, 1953.

Sirks, A.J. Boudewijn. "The episcopalis audientia in Late Antiquity." Droit et Cultures 65 (2013): 79-88.

Sobański, Remigiusz. Europa obojga praw. Katowice: Księgarnia Św. Jacka, 2006.

Stein, Peter. Roman Law in European History. Cambridge, New York: Cambridge University Press, 1999.

Thier, Andreas. "Legal History." In Unexpected Circumstances in European Contract Law, edited by Ewoud Hondius, and Hans Christoph Grigoleit, 15-32. Cambridge: Cambridge University Press, 2011.

Tierney, Brian. Church Law and Constitutional Thought in the Middle Ages. London: Variorum Reprints, 1979.

Uruszczak, Wacław. "Les répercussions de la mort de Thomas Becket en Pologne (XIle-XIIle siécles)." In id., Opera Historico-Iuridica Selecta, 47-61. Kraków: Jagiellonian University Press, 2017.

Uruszczak, Wacław. "Reguła quod omnes tangit debet ab omnibus approbari dawnego prawa kanonicznego i jej znaczenie." In Opera Historico-Iuridica Selecta, 481-494. Kraków: Jagiellonian University Press, 2017.

Usher, Abbott Payson. "The Origin of the Bill of Exchange." Journal of Political Economy 22 (1914): 566-576.

Widlak, Tomasz. "From Vladimiri's just war to Kelsen's lawful war. The universality of the bellum justum doctrine." Studia Philosophiae Christianae 53 (2017): 77-96.

Wieacker, Franz. A History of Private Law in Europe with Particular Reference to Germany, translated by Tony Weir. Oxford: Clarendon Press, 1995.

Wojtczak, Marzena. "Audientia sacerdotalis? Remarks on the Legal Nature of Dispute Resolution by Ecclesiastics in Late Antiquity." Zeitschrift für Antikes Christentum 25.1 (2021): 108-149. 
Ullmann, Walter. Law and Politics in the Middle Ages. An Introduction to the Sources of Medieval Political Ideas. Cambridge: Cambridge University Press, 1975.

Zabłocki, Jan. "Consensus facit nuptias." In Marriage. Ideal - Law - Practice, edited by Zuzanna Służewska, and Jakub Urbanik, 235-247. Warsaw: The Raphael Taubenschlag Foundation, 2005.

Zimmermann, Reinhard. The Law of Obligations. Roman Foundations of the Civilian Tradition. Cape Town, Wetton, Johannesburg: Juta \& Co. Ltd., 1990.

Zwalve, Willem Jans, and Boudewijn Sirks. Grundzüge der Europäischen Rechtsgeschichte. Einführung und Sachenrecht. Wien, Köln, Weimar: Böhlau Verlag, 2012. 
